\title{
Review and Evaluation of Residue Carbonization in the Consol Synthetic Fuel Process
}

\author{
J. B. Gibson \\ F. J. Endelman
}

\section{OAK RIDGE NATIONAL LABORATORY}




\section{DISCLAIMER}

This report was prepared as an account of work sponsored by an agency of the United States Government. Neither the United States Government nor any agency Thereof, nor any of their employees, makes any warranty, express or implied, or assumes any legal liability or responsibility for the accuracy, completeness, or usefulness of any information, apparatus, product, or process disclosed, or represents that its use would not infringe privately owned rights. Reference herein to any specific commercial product, process, or service by trade name, trademark, manufacturer, or otherwise does not necessarily constitute or imply its endorsement, recommendation, or favoring by the United States Government or any agency thereof. The views and opinions of authors expressed herein do not necessarily state or reflect those of the United States Government or any agency thereof. 


\section{DISCLAIMER}

Portions of this document may be illegible in electronic image products. Images are produced from the best available original document. 
Printed in the United States of America: Available from National Technical Information Service

U.S. Department of Commerce

5285 Port Royal Road, Springfield, Virginia 22161

Price: Printed Copy \$4.00; Microfiche $\$ 2.25$

This report was prepared as an account of work sponsored by the United States Government. Neither the United States nor the Energy Research and Development Administration/United States Nuclear Regulatory Commission, nor any of their employees, nor any of their contractors, subcontractors, or their employees, makes any warranty, express or implied, or assumes any legal liability or responsibility for the accuracy, completeness or usefulness of any information, apparatus, product or process disclosed, or represents that its use would not infringe privately owned rights. 


\section{ORNL/TM-5346}

Contract No. W-7405-eng-26

CHEMICAL TECHNOLOGY DIVISION

Coal Technology Program

REVIEW AND EVALUATION OI' RESIDUE CARBONIZATION

IN THE CONSOL SYNTHETIC FUEL PROCESS

J. B. Gibson

F. J. Endelman

MAY 1976

NOTICE This document contains information of a preliminary nature dird was preparod primarily for internal IIs at the Oak Ridge National Laboratory. It is subject to revislon or correction and therofore does not represent a final report.

OAK RIDGE NATIONAL LABORATORY

Oak Ridge, Tennessee 37830

operated by

UNION CARBIDE CORPORATION

for the 


\section{THIS PAGE}

\section{WAS INTENTIONALLY LEFT BLANK}


TABLE OF CONTEINTS

Page

ABSTRACT. . . . . . . . . . . . . . . . . . 1

1. INTRODUCTION. . . . . . . . . . . . ..... 1

2. OPERATIONAL HISTORY . . . . . . . . . . . . . . 3

3. DESIGN CONSIDERATIONS OF CARBONIZER . . . . . . . . . 9

3.1 Grid Plate................. 9

3.2 Lift Leg . . . . . . . . . . . . . . . 9

3.3 Overall Dimensions of the Carbonizer . . . . . . . . 9

3.4 Cyclones .................. 10

3.5 SIurry Injection Nozzles . . . . . . . . . . 10

4. ORNL RESIDUE CARBONIZATION. . . . . . . . . . . . 10

4.1 Feed System. ................. 10

4.2 Reactor. ................ 16

4.3 Product Recovery ................ 16

4.4 operating Parameters .............. 16

5. REFERENCES. . . . . . . . . . . . . . . . 17 
REVIEW AND EVALUATION OF RESIDUE CARBONIZATION IN THE CONSOL SYNTHETIC FUEL PROCESS.

J. B. Gibson

F. J. Endelman

ABSTRACT

Design and operating experience of the low-temperature carbonizer in the Consol Synthetic Fuel Pilot Plant at Cresap, W. Va., have been reviewed and evaluated as the first phase of a project at ORNL for bench-scale carbonization of residue from coal liquefaction processes. Solids-laden residue from the solid-liquid separation step of a coal liquefaction process may be converted into valuable liquid and gaseous products and dry, free-flowing char by low-temperature carbonization. As a result of this review, the bench-scale carbonizer at ORNL will maintain a high degree of similitude with the Cresap carbonizer for proposed carbonization experiments with $\mathrm{H}$-Coal vacuum distillation bottoms and with solvent extraction underflows from solvent Refined Coal and Consol Synthetic Fuel product Iiquids.

\section{INTRODUCTION}

Devolatilization of solids-laden residue from coal conversion processes in a fluidized-bed carbonizer may assist greatly in solving the serious solid-liquid separation problem faced in coal liquefaction processes. Processing of such materials in the carbonizer may convert an intractable slurry into a bed of dry solids and simultaneously recover liquid values. Reactivation of the $1700-1 \mathrm{~b} / \mathrm{hr}$ lift-leg carbonizer at Cresap, west Virginia, will provide the capability for pilot-scale evaluation of this process. Concurrent bench-scale experiments in the ORNL 10-1b/hr reactor $\mathrm{w} 1 \mathrm{ll}$ permit rapid testing of a variety of feed stocks and provide information for scale-up. 
This project for supporting research and development on residue carbonization is supported by the Division of Coal Conversion and Utilization, ERDA. The work for the year beginning November 1, 1975, consists of three tasks: (1) a review and evaluation of experience with the low-temperature carbonizer in the pilot plant at Cresap, West Virginia; (2) modification of an existing reactor to permit continuous feed of solids-laden residue; and (3) operation of the reactor with three feedstocks [vacuum distillation bottoms from the $\mathrm{H}-\mathrm{Coal}$ process and solvent extraction underflows from Solvent Refined Coal (SRC) and Consol Synthetic Fuel (CSF) product liquids] at three temperatures up to $1200^{\circ} \mathrm{F}$.

The CSF process ${ }^{1-13}$ combines solvent extraction with catalytic hydrogenation to convert coal into a synthetic crude oil (syncrude). Bench-scale work on the process was carried out by the Consolidation Coal Company (Consol.) on a proprietary basis during the period 1949-63. On August 30, 1963, Consol contracted with the Office of Coal Research to pilot plant their process at Cresap, West Virginia, under the code name Project Gasoline. Throughout the period covered by this contract, which extended until August 30, 1972, there were four principal phases of activity: pre-pilot-plant (bench-scale) research, September 1963July 1968; pilot-plant design and construction, June 1964-May 1967; pilot-plant operation, Novenber 1966-Tebruary 1970; and review and evaluation of bench-scale and pilot-plant results, February 1970August 30, 1972.

In the solvent extraction part of the process, coal is dissolved in a process-derived donor solvent, and the resulting liquid-solid mixture is separated into hydrogen-rich liquids and carbon-rich residue. The residue is processed further to recover solvont and char, and to produce fuel gas, tars, and a small amount of syncrude. In the catalyt1c hydrogenation segment of the CSF process, the hydrogen-rich extract is upgraded to syncrude.

The residue carbonization section (Section 800) of the CSF pilot plant is of primary importance to this study. The purposes of this section are: (1) to recover solvent from the extract residue, (2) to 
produce. liquid hydrocarbons from that portion of the coal which was not extracted from the ash, and (3) to produce a char which is a potential by-product in a commercial plant. Consol successfully

accomplished residue carbonization in a fluidized bed in both benchscale $(10-\mathrm{lb} / \mathrm{hr})$ and pilot-plant-scale (20-ton/day) units.

\section{OPERATIONAL HISTORY}

In the early stages of operation of the residue carbonizer, the feed was a mixture of filter cake from the extract separation section of the pllot plant and recycled char. The char was recycled from the first stage of an internal cyclone separator in the carbonizer to ensure that the feed to the carbonizer flowed freely. The heat necessary to vaporize the solvent and carbonize the filter cake at $950^{\circ} \mathrm{F}$ was provided by combusting char with a controlled amount of air. To maintain fluidization velocities in the range of 0.6 to 1.1 fps, fuel gas was recycled at a rate complementary to that of the combustion air. ${ }^{2}$ (Fluidization velocities were later increased to a maximum of $2 \mathrm{fps} .{ }^{5}$ ) Consol reported a design average residence time of solids in the fluid bed of 10 min with a bed height of $12 \mathrm{ft}^{2}$ (However, this appears to be in error, and later references by Consol indicate an average residence time of about $3 \mathrm{hr}$.) The ratio of, char recycle to filter cake feed was controlled by varying the entrainment: rate of solids from the fluidized bed. This, in turn, was controlled by varying the gas velocity, bed height, and particle size distribution in the bed; the latter was manipulated by controlling the amount of fines returned to the bed from the third-stage cyclone.

Char was withdrawn from the carbonizer through a stand-pipe. It fllowed into a water quench tank and then was pumped to a storage pond. Carbonizer gas, after passing through a three-stage cyclone, entered a quench tower maintained at $300^{\circ} \mathrm{F}$ by recycling aqueous liuqids through spray nozzles. It was intended to have most of the solvent and essentially all of the tar and char fines condensed in either this quench tower or in the electrostatic precipitator immediately downstream. The solvent, char, and tar from these two vessels were collected in a tar receiver. A portion of this inventory was recycled back 


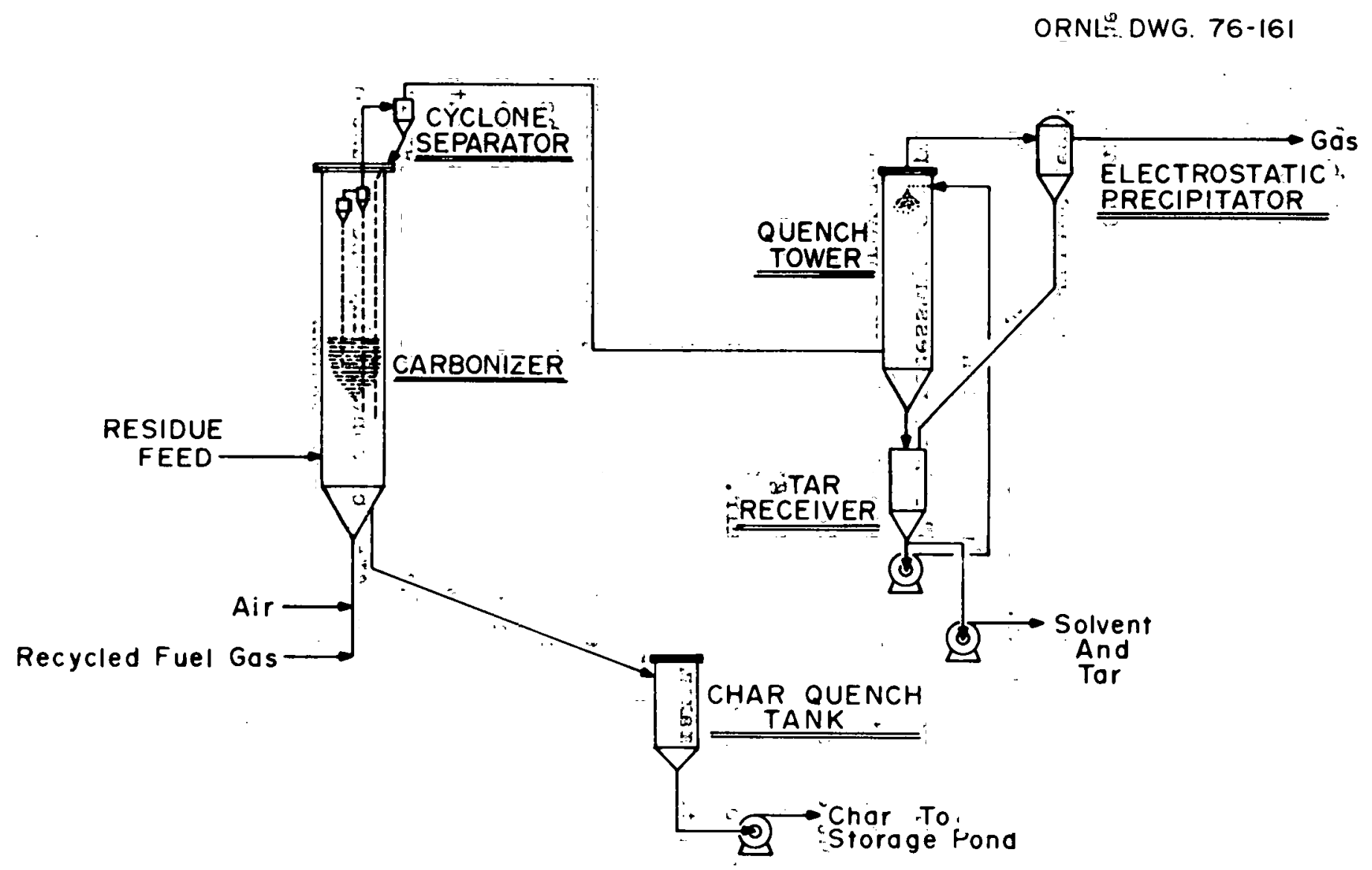

Fig. 1. Simplifị déflowsheet of Consōl residue' cárbōnization. (Redrawn from ref. ${ }^{2}$.): 
to the quench tower, where it was sprayed in at the top to flush the walls of the vessel to prevent deposition of solids and tar. Another portion of this material was returned to residue separation.

Severe problems with the filters in the extract separation section of the pilot plant led Consol to switch to hydroclones as the means for separating extract and residue. As compared with filtration, a hydroclone has a lower solids removal efficiency and produces a higher solvent content in the rejected solids. The feed injection system for the carbonizer had to be revised in order to accommodate hydroclone underflow feed. Provisions were made to inject the slurry directly into the carbonizer through two steam-jacketed spray nozzles (one spare) which were installed $3 \mathrm{ft}$ above the bottom grid. The first-stage cyclone dipleg, instead of extending from the carbonizer to the filter-cake feed mixer, was modified so as to return fines to the fluid bed through a trickle valve.

The most significant difficulty encountered when the feed was introduced as a slurry through the spray nozzle was agglomeration of the char in the carbonizer. The agglomerated material plugged the bed, cyclone, and char withdrawal line, even though the latter had been made flush with the grid plate by that time.

The mode of feed distribution within the bed was believed to be the most important factor influencing particle growth. Thus, a second spray nozzle was installed at a position $11.25 \mathrm{ft}$ above the grid plate. ${ }^{5}$ However, this arrangement provided only sporadic relief. Tn order to increase the dispersion of the feed within the bed, and thereby further reduce agglomeration, it was decided to inject the feed through a spray nozzle inside a lift leg which was 6 in. in diameter by 10 ft 9 in. long. 5 Feed and char moved upward, inside the lift leg, with recycle gas flowing at the rate of 6 to $10 \mathrm{fps}$. The operation via lift leg with respect to particle agglomeration was greatly inproved over that experienced with bed feeding. Although no direct measurements of solid circulation rates were made, it was deduced from a heat balance that the solid circulation rate through the lift leg was on the order 
of $100,000 \mathrm{lb} / \mathrm{hr}$. With a normal bed inventory of $2000 \mathrm{lb}$, this was equivalent to 50 "turnovers" per hour. 5 A schematic of the CSF carbonizer is shown in Fig. 2.

With the feed rates used in most runs and the normal bed irventory of $2000 \mathrm{lb}$, the solids residence time was about $3 \mathrm{hr}$. Previous work by Consol on fluidized carbonization of Pittsburgh seam coal had indicated that a residence time of $70 \mathrm{~min}$ at $800^{\circ} \mathrm{F}$ or $15 \mathrm{~min}$ at $900^{\circ} \mathrm{F}$ was adequate to devolatilize $90 \%$ of the coal slurry recoverable at that temperature with infinite residence time. ${ }^{5}$

Tar yields were correlated as a function of the Fischer assay tar yield of solvent and ash-free feed. The Fischer assay is normally run at a constant temperature of $500^{\circ} \mathrm{C}$. Since the carbonizer temperature varied both during and between runs, it was necessary to correct the Fischer assay yield for temperature. The correction was based on a series of bench-scale studies and Fischer assays performed by Consol.

In the carbonizer material balances, char yields were determined by ash balance and liquid yields were determined by difference after allowance for measured gas input and output. Since the net liquid yield was on the order of $5 \%$ of the feed to the carbonizer, small errors in the feed or product analyses could result in a significant error in the calculated net carbonization liquid yield. ${ }^{5}$ A representative carbonizer material balance (i.e., that for run 55-X) is shown in Table 1.

Calculated gross heating values for carbonizer vent gas were fairly low because of the high heat requirement for carbonization. Consol suggested that separation of the combustion and carbonization zones within the carbonizer, as is done in the fluid coking of petroleum, might result in a greater recovery of by-product gases with heating values in excess of $600 \mathrm{Btu} / \mathrm{lb}$. 


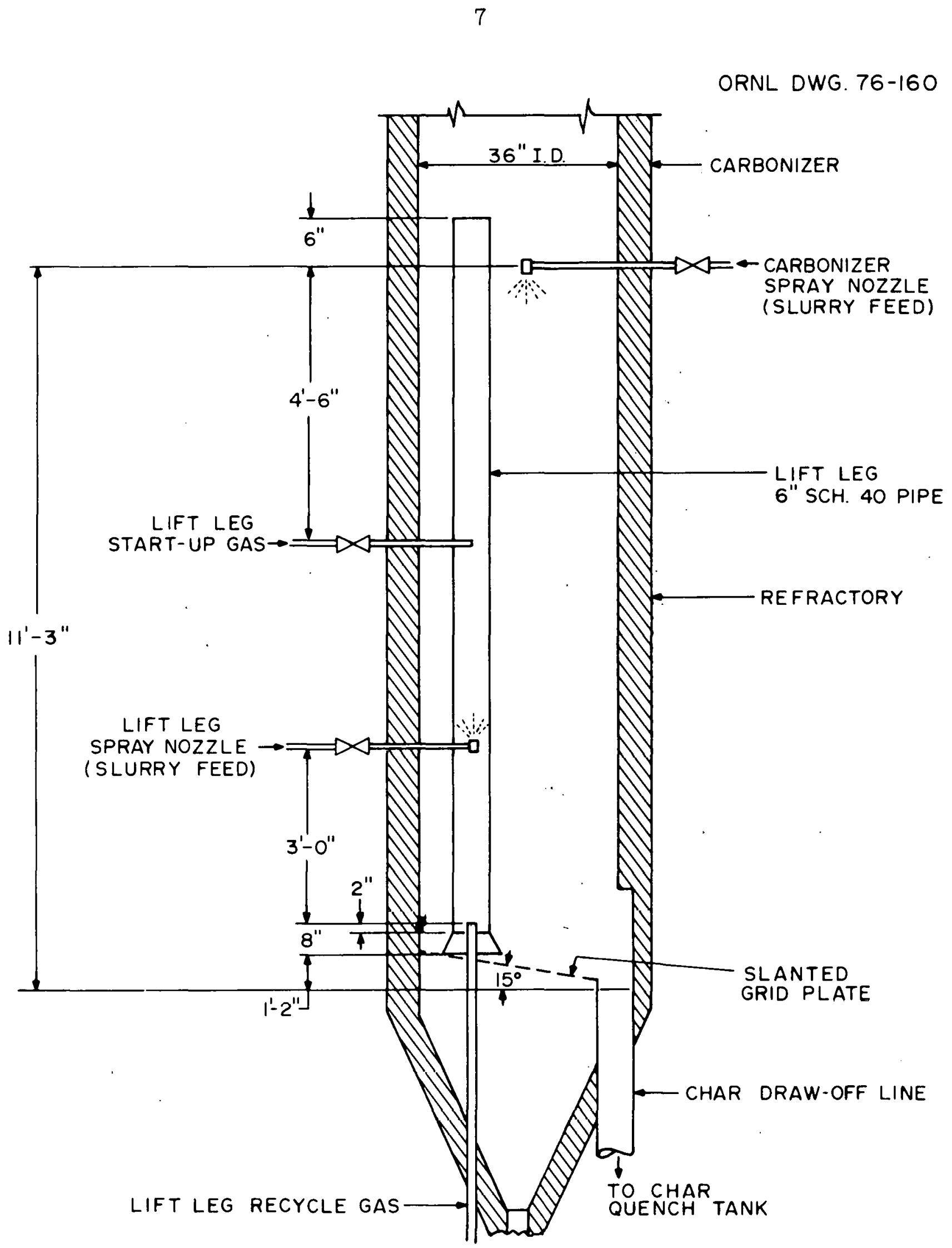

Fig. ¿. Details of Consol carbonizer. (Redrawn from ref. 5.) 
Table 1. Carbonizer material balance for Run $55-\mathrm{x}^{\mathrm{a}}$

A. Input

Solvent

986

Extract

125

Residue

473

Total slurry feed

1584

Air

464

Steam

37

Purge $\mathrm{N}_{2}$

44

Recycle gas

273

Total feed

2402

B. Output

Solvert and lar.

1054

Char

504

Dry make gas

470

Water

101

Recycle gas

273

Total output

2402

Net tar yield

$68(4.3 \%)$

${ }^{a}$ Data obtained from ref. 5. 


\section{DESIGN CONSIDERATIONS OF CARBONIZER}

\subsection{Grid Plate}

The carbonizer contained a pierced-plate grid to distribute gas into the fluidized bed. In its final design, the grid plate contained fifty-two 9/32-in.-diam ( $0.3 \%$ open area) holes arranged in a concentrj.c circular pattern. The grid plate was tilted at an angle of $15^{\circ}$ to the horizontal in order to promote travel of large char particles to the bottom draw-off pipe. Operational pressure drops ranged from 0.2 to $0.4 \mathrm{ps} 1$, which were equivalent to 10 to $20 \%$ of the total pressure drop across the bed. 5

\section{2 Iift Ieg}

The carbonizer contained an internal vertical p1pè, 6 in. in diameter by $10 \mathrm{ft} 9 \mathrm{in.}$ long, which was designed to achieve a high forced circulation of char past the feed spray nozzle. This was accomplished by injecting recycle gas into the base of the pipe, or lift leg, in order to entrain solids from the main body of the fluid bed. Solids were conveyed to the top of the lift leg by gas traveling at superficial velocities on the order of 6 to 10 fps. Although no direct measurements of solids circulation rates were made, Consol estimated that the lift leg experienced 50 inventory turnovers per hour.

\subsection{Overall Dimensions of the Carbonizer}

The carbonizer consisted of a vertical vessel, $48 \mathrm{in.} \mathrm{OD} \mathrm{by} 28 \mathrm{ft}$ high, that had a conical bottom and a flat-plate top. The lower $20 \mathrm{ft}$ of the vessel contained $6 \mathrm{in}$. of internal insulation so that this section had a nominal inside diameter of $36 \mathrm{ln}$. The carbonizer, which was made of ASTM 201 Grade A carbon steel, was designed to operate at 25 psig with a maximum temperature of $1000^{\circ} \mathrm{F}$. 


\subsection{Cyclones}

A three-stage cyclone with a low pressure drop was located within the carbonizer vessel. Diplegs returned solids to the fluidized bed. The total amount of dust leaving the third stage varied from 0.3 to 5.0 grains per actual cubic foot. 5

\subsection{Slurry Injection Nozzles}

The internals of the spray nozzles were fabricated of tungsten carbide and were designed to produce a hollow cone spray with an $80^{\circ}$ angle. Two nozzle orifice diameters of 0.25 and 0.213 .in. were tested; the latter was eventually selected in order to provide a pressure drop of 60 to $100 \mathrm{psi}^{5}$

\section{ORNL RESIDUE CARBONIZATION}

ORNL has been instructed by the ERDA/FE work statement for residue carbonization to: (I) modify and utilize an existing atmospheric hydrocarbonization reactor for this work, and (2) establish optimum temperature and feed rates for recovering $90 \%$ of the volatile material contained in H-Coal vacuum distillation residuum and SRC and CSF solvent extraction underflows. In order to accomplish these objectives, it was necessary to review the operation of the Consol (CSF) carbonizer. The review enabled the establishment of the required modifications to the existing bench-scale atmospheric hydrocarbonization reactor ${ }^{14-17}$ and the operating parameters of the experimental matrix of the program. A schematic of this system is shown in Fig. 3. Further details of the feed system and the reactor are shown in Figs. 4-7. Modifications to the bench-scale reactor system are described below.

\subsection{Feed System}

In order to operate the reactor continuously, it is necessary to add a feed system to the reactor. Two possible feed systems are being pursued. One of these (see Fig. 2) feeds finely ground particles of 


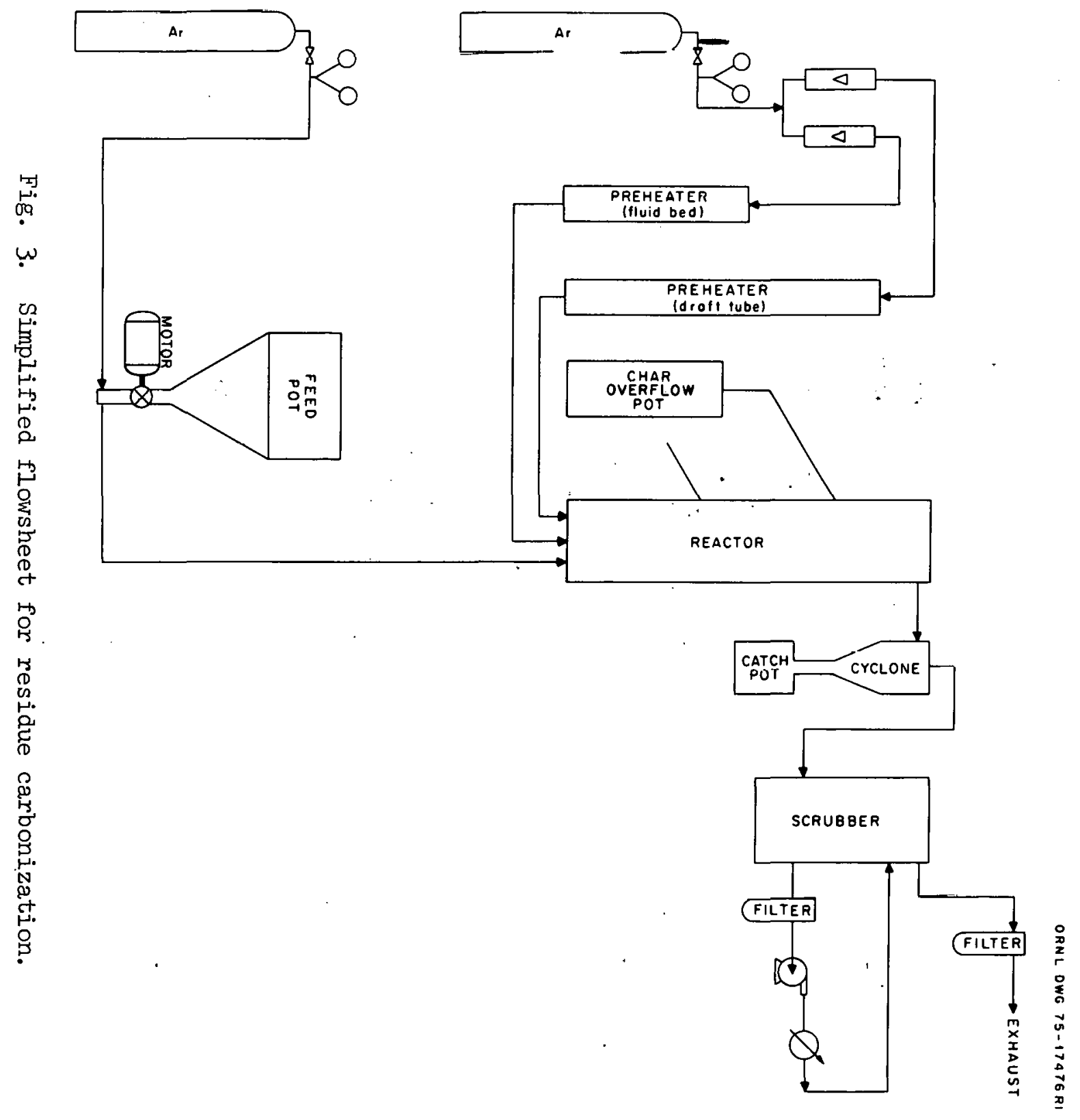


ORNL OWG 75-17481R2

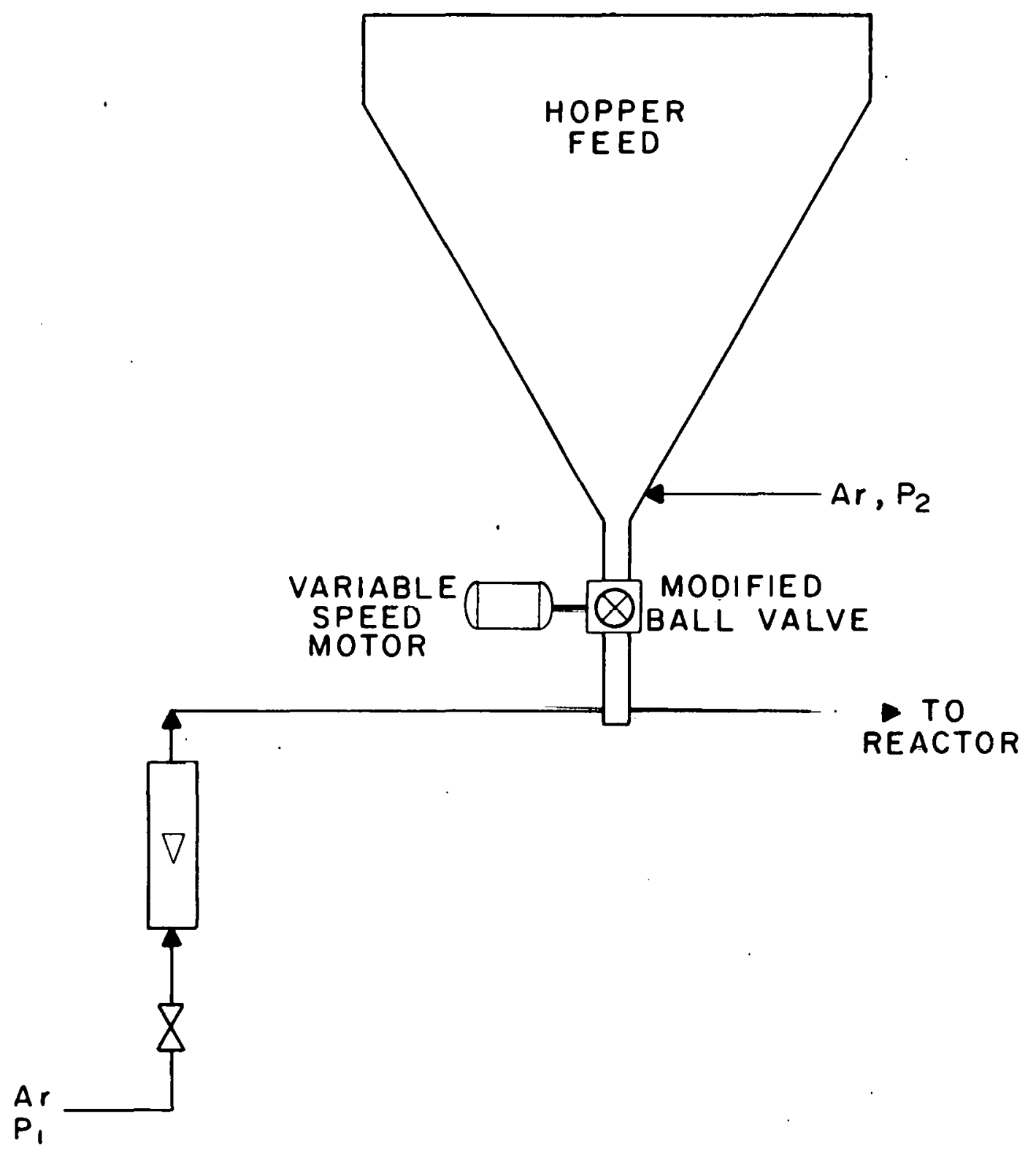

Fig. 4. Residue carbonization feed system. 

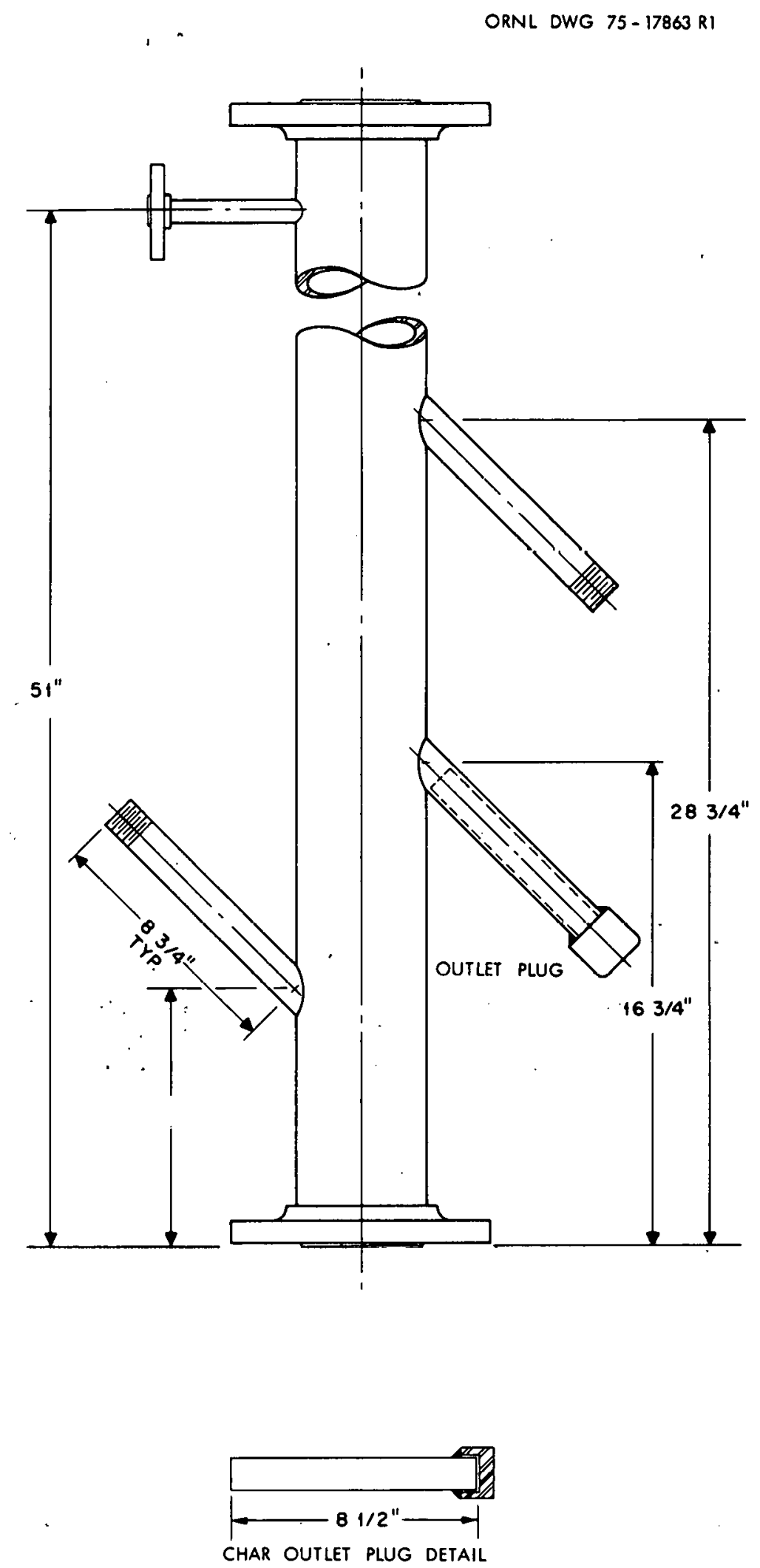

Fig. 5. Residue carbonization reactor. 
OANL OWG 75-17864R2
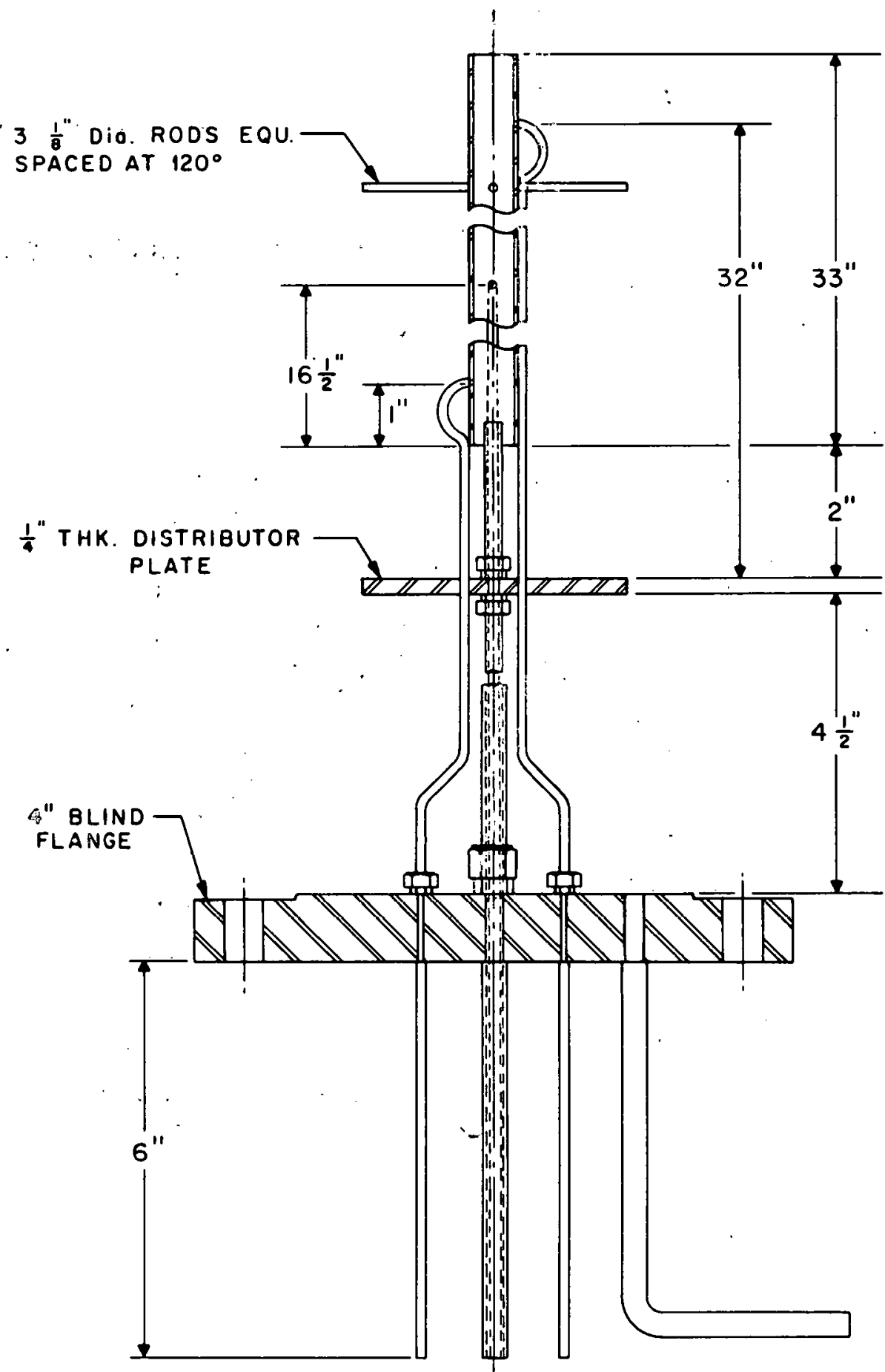

Fig. 6. Details of draft tube used in residue carbonization reactor. 
ORNL DWG 75-17480RI

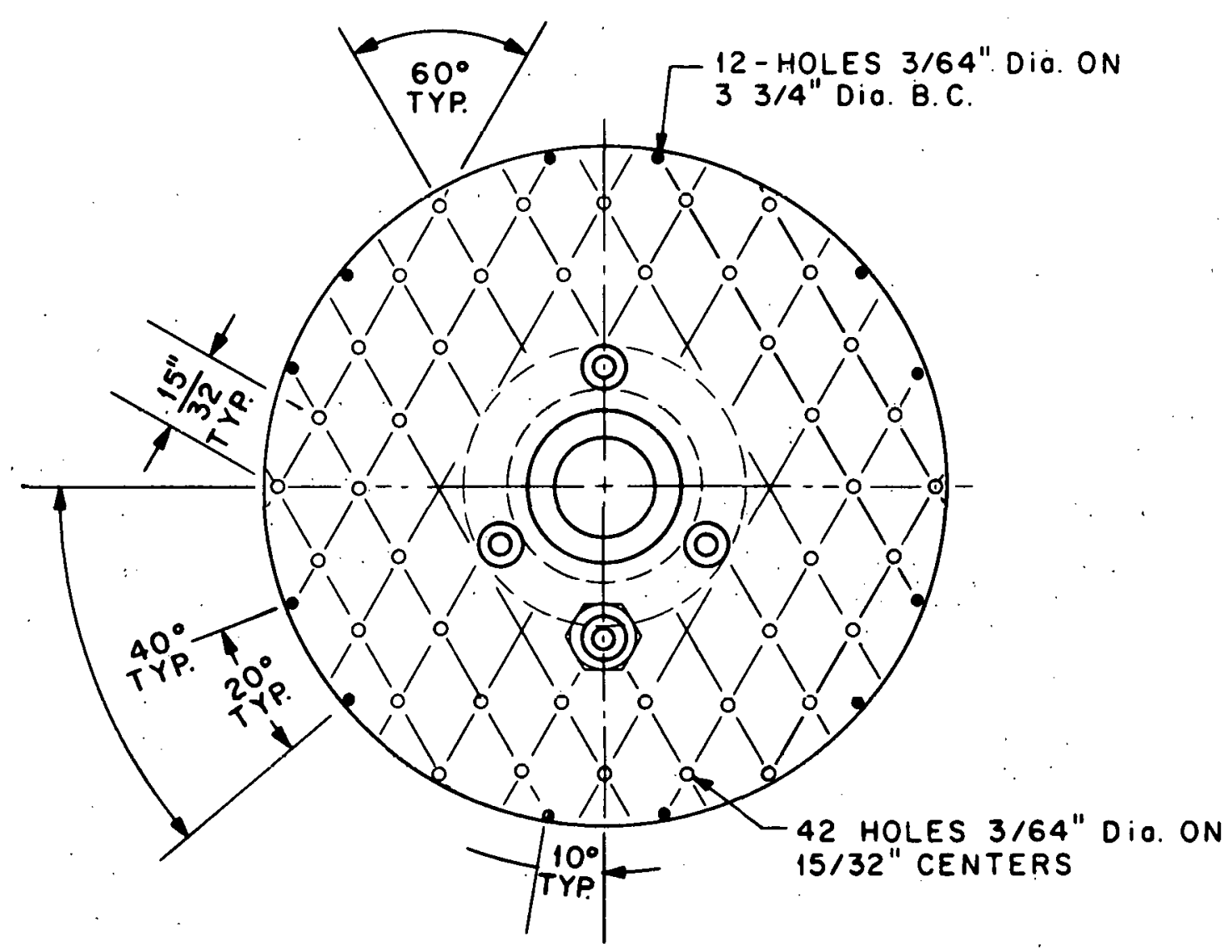

Fig. 7. Residue carbonization distributor plate. 
residue through a modified ball valve and to the reactor via pneumatic transport. A second system, which is being investigated in the event that the first should prove to be unsuccessful, would mix finely ground residue with toluene to form a slurry which is 25 to 50 wt \% toluene. The slurry would then be pumped and sprayed into the reactor. The residue feed rate is expected to be about $10 \mathrm{lb} / \mathrm{hr}$; the capacity of the feed vessel is about $50 \mathrm{lb}$.

\subsection{Reactor}

Figures 3-5 show the details of the reactor modifications. The reactor, which is a 55-in.-Iong section of 4-in.-diam sched 40 pipe, has two char overflow pipes which determine the height of the fluidized bed. The lift leg (draft tube) consists of a 33-in. length of 3/4-in.-. diam stainless steel tubing. It is possible to shorten the draft tube to as little as 17-1/2 in. if necessary. Residue feed will be injected directly into the base of the draft tube. Argon, with velocities of 5 to 11 fps in the draft tube and 0.3 to $2.3 \mathrm{fps}$ in the fluidized bed, will be used as the fluidizing gas. All components of the reactor are made of series 300 stainless steel.

\section{4:3 Product Recovery}

The liquid product recovery system is unchanged from the atmospheric hydrocarbonization system. It consists of a scrubber, a gas filter, and a liquid filter. A solids recovery system has been fabricated to allow recovery of char product from the reactor. The char falls through an overflow leg on the reactor into a cylindrical overflow pot.

\subsection{Operating Parameters}

Experiments will be run on each of the three feedstocks at 900, 1050, and $1200^{\circ} \mathrm{F}$. The reactor will be fluidized by argon gas at 
essentially atmospheric pressure. Fluidizing velocities will be 5 to 11 fps in the draft tube and 0.3 to $2.3 \mathrm{fps}$ in the fluidized bed. The residue feed rate will be approximately $10 \mathrm{lb} / \mathrm{hr}$. A comparison between the operating parameters of the CSF carbonizer and the ORNL carbonizer is shown in Table 2 .

Table 2. Comparison of carbonizer operating parameters

\begin{tabular}{lll}
\hline \multicolumn{1}{c}{ Parameter } & CSF & carbonizer \\
\hline Pressure, psig & ORNL carbonizer \\
Temperature, ${ }^{\circ} \mathrm{F}$ & 15 & $<5$ \\
Llft=leg velocity, fps & $800-950$ & $900-1200$ \\
Fluid-bed velocity, fps & $6-10$ & $5-11$ \\
Solid residence time, min & $0.6-2.0$ & $0.3-2.3$ \\
Bed depth/bed diameter & $10-180$ & $10-160$ \\
Bed diameter/lift-leg diameter & 4 & 3 or 6 \\
Bed turnovers/hr & 6 & 5.3 \\
Turnover rate/feed rate & $\sim 50$ & $\leq 300$ \\
\end{tabular}

$a_{\text {Dala }}$ obtained from ref: 5 .

\section{REFEREINCES}

1. Coal Extraction, Extract Filtration, and Extract Deashing, U.S. Dept. of the Interior, Office of Coal Research, OCR Report No. 39, Interim Report No. I for Period August 1963 - June 1969, prepared by Consolidation Coal Co.

2. Design and Construction of the CSF Pilot Plant, Cresap, W. Va., U.S. Dept. of the Interior, Office of Coal Research, OCR Report No. 39, Interim Report No. 3 for Period August 1963 - June 1968, prepared by Consolidation Coal Co. (September 1968). 
3. Startup and Initial Operations at Cresap Pilot Plant, U.S. Dept. of the Interior, Office of Coal Research, OCR Report No. 39, Interim Report No. 4 for Period November 1966 - June 1968, prepared by Consolidation Coal Co.

4. Summary Report on Project Gasoline, U.S. Dept. of the Interior, Office of Coal Research, OCR Report No. 39, Interior Report No. 5 for Period September 1963 - June 1969, prepared by Consolidation Coal Co.

5. Pilot-Scale Development of the CSF Process, U.S. Dept. of the Interior, Office of Coal Research, OCR Report 39, Interim Report No. 6 for Period JuIy 1968 - December 1970, prepared by Consolidation Coal Co.

6. Development of CSF Coal Liquefaction Process, U.S. Dept. of the Interior, Office of Coal Research, OCR Report No. 39, Final Report, prepared by Consolidation Coal Co. (April 1973).

7. Consol Synthetic Fuel Process Development Monthly Progress Reports Numbers 1 through 116, U.S. Dept. of the Interior, Office of Coal Research, prepared by Consolidation Coal Co. (July 1974).

8. Consol Synthetic Fuel Process: 1968 Feasibility Report, U. S. Dept. of the Interior, Office of Coal Research, OCR Report No. 45, Interim Report No. I for Period May 1962 - October 1968, prepared by Ralph M. Parsons Company.

9. Consol Synthetic Fuel Process: 1968 Feasibility Report, U. S. Dept. of the Interior, Office of Coal Research, OCR Report No. 45, Addendum to IR No. 1 for Period May 1962 - October 1968, prepared by Ralph M. Parsons Company.

10. 1969 Feasibility Report Consol Synthetic Fuel Process Synthetic Crude Production, U.S. Dept. of the Interior, Office of Coal Research, OCR Report No. 45, Interim Report No. 2 for Period May 1962 - May 1969, prepared by Ralph M. Parsons Company.

11. 1970 Final Report Consol Synthetic Fuel Process, U. S. Dept. of the Interior, Office of Coal Research, OCR Report No. 45, Final Report, prepared by Ralph M. Parsons Company. 
12. Evaluation and Recommendations Concerning the Design, Construction, and Operation of Consol Synthetic Liquid Fuel Pilot Plant, U.S. Dept. of the Interior, Office of Coal Research, OCR Report No. 50, Final Report for Period December 1968 - January 1970, prepared by W. C. Schroeder and Associates.

13. Engineering Evaluation of Project Gascline Consol Synthetic Fuel Process, U.S. Dept. of the Interior, Office of Coal Research, OCR Report No. 59, Final Report, prepared by Foster Wheeler Corporation.

14. Coal Technology Program Quarterly Progress Report No. I for the Period Ending December 31, 1974, ORNL-5026 (April 1975).

15. Coal Technology Program Quarterly Progress Report No. 2 for the Period Ending March 31, 1975, ORNL-5049 (August 1975).

16. Coal Technology Program Annual Interin Report for Fiscal Year Ending June 30, 1975, ORNL-5069 (October 1975).

17. Coal Technology Program Quarterly Progress Reporit for the Period Ending September 30, 1975, ORNL-5093 (December 1975). 
THIS PAGE

\section{WAS INTENTIONALLY LEFT BLANK}


INTERNAL DISTRIBUTION

1. R. G. Affel

2. T. D. Anderson

3. S. I. Auerbach

4. J. K. Baird

5. R. E. Barker

6. H. C. Beeson

7. M. Bender

8. B. G. Blaylock

9. N. E. Bolton

10. R. E. Brooksbank

11. D. A. Canonico

12. J. A. Carter

13. H. D. Cochran, Jr.

14. E. Copenhaver

15. L. T. Corbin

16. D. A. Creasia

17. O. I. Culberson

18. F. I. Culler

19. J. E. Cunningham

20. V. A. DeCarlo

21. D. G. Doherty

22. M. S. Edwards

23-27. F. J. Endelman

28. G. G. Fee

29. D. E. Fergus on

30. L. M. Ferris

31. R. C. Forrester III

32. A. P. Traas

33. W. Fulkers on

34. W. R. Gambill

35. D. A. Gardiner

36. C. W. Gehrs

37-41. J. B. Giuson

42. W. I. Greenstreet

43. M. R. Guerin

44. C. W. Hancher

45. I. A. Harris

46. S. E. Herbes

47. S. G. Hildebrand

48. R. M. Hill

49. R. S. Holcomb

50. J. M. Holmes

51. R. B. Honea

52. J. K. Huffstetler

53. C. L. Hunt

54. G. R. Jasny, $Y-12$
55. L. I. Johnston

56. R. I. Jolley

57. J. E. Jones

58. D. S. Joy

59. S. Katz

60. O. L. Keller

61. R. F. Kimball

62. W. R. Laing

63. R. S. Livingston

64. A. P. Malinauskas

65. G. B. Marrow, Y-12

66. W. R. Martin

67. C. J. McHargue

68. J. R. McWherter

69. H. J. Metz

70. W. R. Mixon

71. J. E. Mrochek

72. P. Nettesheim

73. J. P. Nichols

74. I. C. Oakes

75. G. R. Peterson

76. T. W. Pickel

77. W. W. Pitt

78. H. Postma

79. W. T. Rainey

80. D. E. Reichle

81. C. R. Richmond

82. B. R. Rodgers

83-84. M. W. -Rosenthal

85. T. H. Row

86. W. L. Russell.

87. Royes Salmon

88. R. W. Schede, Y-12

89. C. D. Scott

90. D. S. Shriner

91. W. D. Shults

92. C. B. Smith

93. G. P. Smith

94. I. Spiewak

95. R. L. Spore

96. E. G. St. Clair

97. J. B. Storer

98. R. A. Strehlow

99. O. K. Tallent

100. A. J. Thompson

101. D. B. Trauger 
102. W. C. Ulrich

103. P. R. Vanstrum, Y-12

104. J. S. Watson

105. J. R. Weir

106. P. R. Westmoreland

107. M. E. Whatley

108. J. C. White

109. M. K. Wilkins on

110. L. V. Wils on
117. R. G. Wymer

112. G. I. Yoder

113. C. S. Yust

114. Patent office

115-119. Laboratory Records

120. Laboratory Records-RC

121-123. Central Research Library

124. Document Reference Section

\section{EXTERNAL DISTRIBUTION}

ERDA, Oak Ridge Operations

125. Research and Technical Support Division

ERDA, Washington

126. D. Ballantine, DBER

127. J. D. Batchelor, F

128. T. Beresovski, DRRD

129. E. L. Clark, FE

130. N. P. Cochran, FE

131. C. W. Edington, DBER

132. R. Franklin, DBER

133. S. W. Gouse, FE

134. W. S. Harmon, FE

135. G. E. Larson, $\mathrm{FE}$

136. T. K. Lau, F'E

137. R. W. A. LeGassie, AA/PA

138. J. L. Liverman, AA/ES

139. W. G. McDaniel, FE

140. C. Miller, FE

141. G. A. Mills, FE

142. W. E. Mott, DBER

143. M. B. Neuworth, FE

144. E. S. Pierce, DPR

145. H. E. Podall, FE

146. J. I. Powell, FE

147. Robert Rabin, DBER

148. E. Schmetz, F'E

149. G. Stapleton, DBER

150. D. K. Stevens, DPR

151. R. E. Vener, $F$

152. H. Wasson, DBER

153. P. C. White, AA/FE

154. P. R. Wieber, FE

155. R. L. Zahradnik

Department of Housing and Urban Development, 4517 th Street, S.W., Washington, D.C. 20410

156. G. S. Leighton

157. J. H. Rothenberg

National Science Foundation, 1800 G. Street, N.W., Washington, D.C. 20550 158. R. S. Goor

159. Charles Johnson

Resource Planning Associates, Inc., 44 Brattle St., Cambridge, Mass. 02138 160. Robert Rea

U.S. Environmental Protection Agency, ETRL, 1055 Laidlaw, Cincinnati, Ohio 45237

161. William E. Pepelko

U.S. Environmental Protection Agency, Research Triangle Park, NC 27711

162. Charles B. Sedman

U.S. Steel Corp. Applied Research Laboratory, 125 Jamis on Lane, Monroeville, Pa. 15146

163. N. S. Boodman, Section Supervisor. 
University of Kentucky, Institute for Mining and Materials Research, 213 Bradley $\mathrm{Hall}$, Lexington, Kentucky 40506

164. Theresa Wiley, Institute Librarian

165. 0. J. Haun

166. J. K. Shou

167-178. ERDA Pittsburgh Energy Research Center, U.S. Energy Research and Development Administration, Attention: Director for J. P. Barreca, 4800 Forbes Ave., Pittsburgh, Pa. 15213

179-185. The Director, Morgantown Energy Research Center, P. 0. Box 800, Morgantown, West Virginia 26506

186. A. K. Ingberman, I Penn Plaza, Union Carbide Corporation, New York, New York 10001

187. R. E. Davis, Kerr-McGee Technical Center, P. O. Box 25861, Oklahoma City, Oklahoma 73125

188. H. Beuther, Gulf Research and Development Company, P. 0. Drawer 2038, Pittsburgh, Pa. 15230

189. Robert Hangebrauck, National Environmental Research Center, Research Triangle Park, North Carolina 27711

190. P. H. Given, Pennsylvania State University, College of Earth and Mineral Sciences, University Park, Pa. 16802

191. John W. Larson, Department of Chernistry, University of Tennessee, Knoxville, TN 37916

192. Wendall H. Wiser, University of Utah, Department of Mineral Engineering, Salt Lake City, Utah 84112

193. William A. Peters, Massachusetts Institute of Technology, Department of Chemical Engineering, Cambridge, Mass. 02139

194. Donald Hanson, University of California, Department of Chemical Engineering, Berkeley, California 94720

195. S. G. Wellborn, Manager, Feedstocks Development, E. I. du Pont de Nemours \& Company, Inc., Wilmington, Delaware 19898

196. Tetra Tech, Inc., 1911 N. Ft. Myer Drive, Suite 601, Arlington, Virginia 22209, Attention: Walter McGough, Jr.

197-198. Jack Gillespie, UCCID, P. O. Box 1410, Paducah, Ky. 42001

199. Jerry D. Kennedy, Sandia Laboratories, P. O. Box 5800, Albuquerque, New Mexico 87115

200. Prof. S. K. Chakrabartty, University of Alberta, Edmonton, Alberta, Canada

201. L. B. Batta, Coalcon, P. O. Box 44, Tonawanda, N.Y. 14150 202-228. Technical Information Center, ERDA-OR. 